
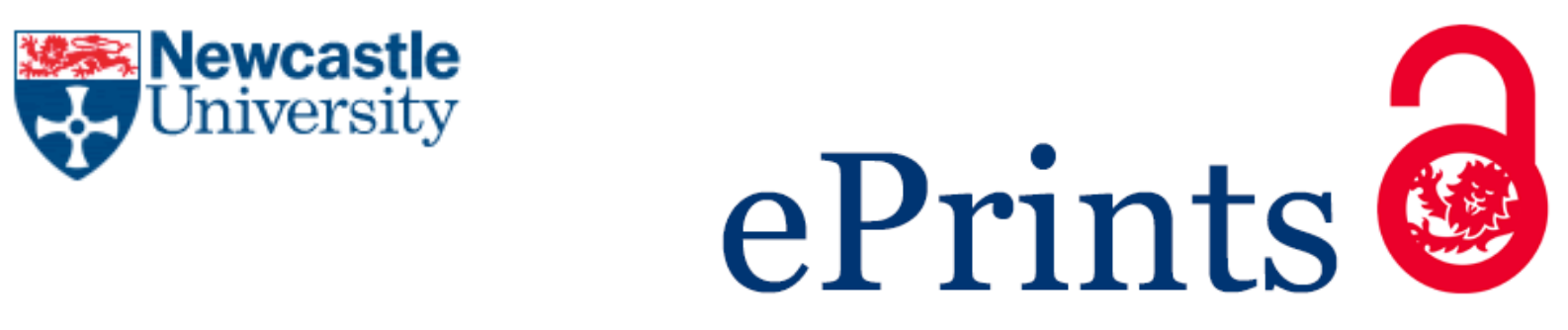

De-Rycker K.

The political function of Elizabethan literary celebrity. Celebrity Studies 2017, 8(1), 157-161

\title{
Copyright:
}

This is an Accepted Manuscript of an article published by Taylor \& Francis in Celebrity Studies on $7^{\text {th }}$ February 2017, available online: http://www.tandfonline.com/10.1080/19392397.2016.1275323

DOI link to article:

http://dx.doi.org/10.1080/19392397.2016.1275323

Date deposited:

$08 / 02 / 2017$

Embargo release date:

08 August 2018

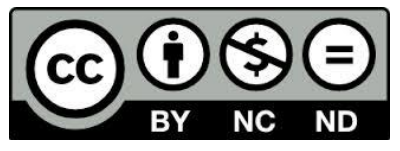

This work is licensed under a

Creative Commons Attribution-NonCommercial-NoDerivatives 4.0 International licence 


\section{The political function of Elizabethan celebrity}

Kate De Rycker

Newcastle University

Anachronistic as the idea of 'celebrity' in the late sixteenth century may seem, what this brief study hopes to show is how one Elizabethan phenomenon, the Martin Marprelate Controversy, relied on a nascent form of celebrity to engage new and wider audiences for political discourse. "Martin Marprelate" was the literary persona used to anonymise a group of puritans who attacked the Church of England in a hail of paper bullets in 1588-9. ${ }^{1}$ Their seven tracts became a phenomenon not so much because their suggestions for overhauling the hierarchy of the Church were especially radical: these ideas had been presented decades before by Presbyterian writers such as Thomas Cartwright and John Field. ${ }^{2}$ They were, however, the first to use an irreverent prose style to package sophisticated ideas of church governance as entertainment. Writing as a figure who would 'mar' the 'prelates' of the established Church, they addressed an audience usually left out of ecclesiastical discussion, through short, ephemeral and accessible polemic. They borrowed techniques from jest-books and the stage, such as feigned naivety and ad hominem attacks on individual bishops. Unsurprisingly, this technique was not approved of by their fellow non-conformists, but the collective justified the use of comedy in their fourth tract 'Hay any Work for Cooper?' (1589) as a way of reaching a new audience:

"The most part of men could not be gotten to read anything written in the defence of [Presbyterianism]. I bethought me therefore of a way whereby men might be drawn to do both, perceiving the humors of men in these times...to be given to mirth.... mirth I used as a covert, wherein I would bring the truth into light." 3

\footnotetext{
${ }^{1}$ In his edition, Joseph L. Black discusses the difficulty, still, of identifying the number and names of Marprelate authors, though the Welsh cleric John Penry and the gentleman Job Throkmorton certainly seem to have been involved in the project. The Martin Marprelate Tracts: A modernized and Annotated Edition (Cambridge: Cambridge University Press, 2008) xxxiv-xlvi. Further references are to this edition.

2 Examples of the Presbyterian platform which Marprelate drew on can be found in Peter Milward ed. Religious Controversies of the Elizabethan Age: A Survey of Printed Sources (Nebraska: University of Nebraska Press, 1977)

${ }^{3}$ The Martin Marprelate Tracts, p.115
} 
This tactic seemed to have been successfulLater depositions reveal that, despite working with a covert press while the authors were trying to escape the authorities, the Marprelate print run was between 1,000 to 1,500 copies per title, which is significant in the context of the average print-run of this period, estimated by Peter Blayney at 800 copies. ${ }^{4}$ Looking back at this popular phenomenon, one later commentator remarked how "speedily dispers'd, how generally bought, how greedily read, and how firmly believed" the tracts were, "especially of the common sort, to whom no better musick than to hear their betters upbraided." ${ }^{5}$

At the end of the sixteenth century, the increasing availability of cheap print meant that for popular writers and polemicists, the ability to reach and persuade the public had become decentralised. ${ }^{6}$ As Peter Lake and Steve Pincus have argued, while there was no permanent public sphere in Elizabethan England, various transient public spheres were brought into being through the circulation of print and manuscript, and through the oral transmission of sermons and drama. State matters were discussed (relatively) more openly, though this discourse was dominated by traditional elites. ${ }^{7}$ What was unusual about the Marprelate writers was not their backgrounds (their most prominent member, Job Throckmorton, was an aristocrat) but rather that they were trying to alter the rules of political engagement, by using humour and notoriety to popularise a serious political message with a wider public audience.

Initially the Marprelate Tracts were met by theological responses preached and written by establishment heavy-weights, only for this official anti-propaganda to be mocked by Marprelate in subsequent pamphlets for its verbosity. An alternative method was needed, and eventually a group of professional writers were engaged, seemingly at the behest of

\footnotetext{
${ }^{4}$ On the Marprelate print run, see Joseph Black's website which transcribes and narrates the documents relating to the controversy: http://people.umass.edu/marprelate/achronologicalnarrative.html. On the average print run in the Elizabethan period, see Peter Blayney, 'The Pubication of Playbooks', in A New History of Early English Drama ed. John D. Cox and David Scott Kastan, (New York: Columbia University Press, 1997) 383-422, p.396

${ }^{5}$ Thomas Fuller, The Church-history of Britain from the birth of Jesus Christ until the year M.DC.XLVIII (London: Printed for John Williams, 1655) p.193

${ }^{6}$ This is the argument of Joad Raymond in his introduction to The Oxford History of Popular Print Culture: Cheap Print in Britain and Ireland to 1660 vol.1 (Oxford: Oxford University Press, 2011) 1-14, p.3

${ }^{7}$ Peter Lake and Steven C. A Pincus, 'Rethinking the public sphere in early modern England', in Peter Lake and Steven C. A. Pincus (eds.), The politics of the public sphere in early modern England (Manchester: Manchester University Press, 2007), 1-30.
} 
Archbishop Whitgift's chaplain, Richard Bancroft, to respond to these anonymous tracts in the language he had used to popularise his religious polemic. This group of writers included Thomas Nashe, John Lyly, Robert Greene, and Anthony Munday, all of whom were from middling backgrounds, and as satirists and playwrights, they were familiar with Marprelate's comic and theatrical style. In addition to printed responses to Marprelate, theatre companies such as Lord Strange's Men were putting on shows for public audiences lampooning Marprelate. These performances were, as far as we know, independently organised and not instigated by representatives of the established Church. ${ }^{8}$

Marprelate had created a form of celebrity for himself, as opposed to fame- if we consider 'fame' as a status achieved for a lifetime of heroic acts, while 'celebrity' is "status on speed. It confers honor in days, not generations." ${ }^{\prime 9}$ This definition implies that 'fame' is the preserve of that society's elite, a reaffirmation of their social position, while 'celebrity' can be gained through opportunistic uses of media, resulting in a fast and seemingly random gaining of power and influence. ${ }^{10} \mathrm{It}$ is a form of public recognition which has potentially destabilising consequences: not only for the individual 'celebrity', but for the society he or she lives in.

'Martin Marprelate' may have been a fictional character, but he was still a public persona, recognised by name, and associated with subversion. The word 'Marprelate' had 'surplus value' as Robert van Krieken has described celebrity, or 'affective presence' as the theorist of early modern cultural icons, Bryan Reynolds, terms a "combined material, symbolic, and imaginary existence."11 The team behind 'Martin Marprelate' may have learned how to create such a persona from their later opponent, Robert Greene, who had become a recognisable literary figure in part through blurring the line between autobiography and fiction in his writing. ${ }^{12}$ 'Marprelate' himself refers to the way his celebrity has amplified his

\footnotetext{
${ }^{8}$ See Lawrence Manley \& Sally-Beth MacLean, Lord Strange's Men and Their Plays (New Haven: Yale University Press, 2014) pp.37-41

${ }^{9}$ Charles Kurzman et al. 'Celebrity Status', Sociological Theory 25:4 (2007) 347-67. p.347

${ }^{10}$ See P.D. Marshall, Celebrity and power: fame in contemporary culture (Minneapolis: University of Minessota Press, 1997)

${ }^{11}$ Robert van Krieken, Celebrity Society (Abingdon; New York: Routledge, 2012) p.10. Bryan Reynolds. Becoming Criminal: Transversal Performance and Cultural Dissidence in Early Modern England. (Cambridge: Cambridge University Press, 2002) p.6

${ }^{12}$ On Greene's persona, see Kirk Melnikoff and Edward Gieskes, eds. Writing Robert Greene: Essays on England's First Notorious Professional Writer (London: Routledge, 2008). The question of fame resulting from the fictionalisation of the authorial persona is also discussed by Antoine Lilti in 'The Writing of Paranoia: JeanJacques Rousseau and the Paradoxes of Celebrity', Representations, 103. 1. (Summer 2008) 53-83, and by Rebbeca Braun, 'Cultural Impact and the Power of Myth in Popular Public Constructions of Authorship', in
} 
political message, when he threatens that his name recognition is stronger than any one individual: "For the day that you hange Martin assure your selves there wil be 20. Martins spring in my place." ${ }^{13}$

While the anonymity of Marprelate was born of pragmatism to avoid capture by the authorities, what their entertaining polemic showed was that the growing availability of printed texts had also made audiences anonymous. Prior to the revolution in cheap print, the majority of writers would be addressing a knowable circle of readers and were therefore able to tailor their writing to their expected audience. As printed work became more widely accessible, audiences were, as as Jeffrey Knapp suggests, increasingly "conceived as massive-which is to say, as indefinite in number, socially diverse, and functionally anonymous". ${ }^{14}$ This resulted in a need for popular writers, such as the Marprelate collective and their detractors, to compensate for the distance between them and their anonymised readers, which had been exacerbated by print. ${ }^{15}$

The Marprelate writers, Nashe, and other professional writers addressed this distance and anonymity by addressing their readers as if they were part of the same virtual community, but the inability to identify who was reading polemic disturbed the authorities. The small size and ephemerality of these pamphlets meant that, hidden away in pockets and interleaved in other books, they could be circulated easily, increasing their political impact through immediacy. The printers and writers of the Marprelate Tracts were eventually discovered and silenced, and while they may not have been able to enforce their religious agenda, they had disrupted the Elizabethan state by showing that unauthorised voices, whether their own or those of their popular opponents, could discuss politically sensitive issues.

Rebecca Braun and Lynn Marven, eds. Cultural Impact in the German Context: Studies in Transmission, Reception and Influence (Rochester, NY: Camden House, 2010) 78-96

13 'The Martin Marprelate Tracts, p.119

${ }^{14}$ Jeffrey Knapp, 'Mass Entertainment before Mass Entertainment', New Literary History, 44:1 (Winter 2013) 93-115. pp.94-5. See also Ian Munro, The Figure of the Crowd in Early Modern London: The City and its Double (New York; Basingstoke: Palgrave MacMillan, 2005); Angela Vanhaelen \& Joseph P. Ward, eds. Making Spaces Public in Early Modern Europe: Performance, Geography, Privacy (Abingdon; New York: Routledge, 2013). Bronwen Wilson \& Paul Yachnin, eds. Making Publics in Early Modern Europe: People, Things, Forms of Knowledge (Abingdon; New York: Routledge, 2010)

${ }^{15}$ See Wes Folkerth, 'Pietro Aretino, Thomas Nashe, and Early Modern Rhetorics of Public Address', in Bronwen Wilson \& Paul Yachnin, eds. Making Publics in Early Modern Europe: People, Things, Forms of Knowledge (Abingdon; New York: Routledge, 2010) 68-80 
The theatre company, Lord Strange's Men, which had symbolically anatomised an embodiment of Marprelate on stage, was reported by the Privy Council as causing "great offence [to] the better sorte [for daring] to handle in their plaies certen matters of Diuinitye and of the State vnfitt to be suffred."16 The politician Francis Bacon also condemned both sides of the debate for legitimising the use of entertainment to engage in state matters, writing that "whatsoever be pretended the people is no meet judg[e] or arbitratour." ${ }^{17}$ The danger that Bacon identified was that of an audience being swayed in political matters by charming and iconic figures. What was quietly revolutionary about this controversy was that the power of persuasion had been shown to lie not only in the hands of traditional authorities, but, increasingly, with individuals who spoke to the people in the language of the stage and the street. Celebrity, in one of its earliest forms, had a subversive political function.

\footnotetext{
${ }^{16}$ Privy Council Minute, $12^{\text {th }}$ November 1589, Letter to Lord Burghley dated 6th November 1589. British Library: MS Lansdowne 60, f.46

${ }^{17}$ Francis Bacon, "An Advertisement touching the Controuersyes of the Church of England ," in Alan Stewart \& Harriet Knight eds., Bacon's Early Writings 1584-1586 (Oxford: Oxford University Press, 2012) p.194
} 